\title{
Modulation of the Transforming Growth Factor $\beta 1$ by Vitamin E in Early Nephropathy
}

\author{
C. Cojocel ${ }^{\mathrm{a}} \quad$ M. Al-Maghrebi ${ }^{\mathrm{b}} \quad$ M.S. Thomson ${ }^{\mathrm{a}} \quad$ P. Rawoot ${ }^{\mathrm{c}} \quad$ R. Raghupathy ${ }^{\mathrm{c}}$ \\ Departments of a Pharmacology and Toxicology, ${ }^{\mathrm{b}}$ Biochemistry and ${ }^{\mathrm{c}}$ Microbiology, Faculty of Medicine, \\ Kuwait University, Safat, Kuwait
}

\section{Key Words}

Diabetic nephropathy • Vitamin E · Lipid peroxidation • TGF- $\beta 1$ mRNA

\begin{abstract}
Objective: The aim of this study was to investigate the pharmacological activity of an antioxidant, $\alpha$-tocopherol (vitamin E, VE) in streptozotocin-induced diabetic rats and study its role in modulating the transforming growth factor $\beta 1$ (TGF- $\beta 1$ ). Methods: Male Sprague-Dawley rats were treated with streptozotocin to induce diabetes. VE and/or insulin (INS) were administered daily during treatment periods of 3, 5, 7 and 10 days. Plasma glucose and fructosamine were measured in diabetic rats at the end of each treatment period. Samples of plasma, urine and renal cortex were analyzed for changes in protein and lysozyme excretion, reduced glutathione and malondialdehyde formation. TGF- $\beta 1$ was determined by ELISA and expression of TGF- $\beta 1$ mRNA was investigated by RTPCR and Northern blot analysis. Results: Diabetes-induced glycemic stress was suppressed by INS, VE or a combination of INS and VE. Diabetes-induced increases of glucose, protein and lysozyme excretion were markedly depressed after 10-day treatment with INS, VE and the combination of INS and VE. Decreased glutathione
\end{abstract}

content in the renal cortex of diabetic rats recovered towards control values, especially after 10-day treatment. Malondialdehyde content increased in diabetic rats and was reduced towards control value following 7- and 10day treatments. Treatment of diabetic rats with INS, VE or the combination of INS and VE decreased elevated TGF- $\beta 1$ in plasma, decreased excretion of TGF- $\beta 1$ in urine, and decreased renal cortex TGF- $\beta 1$ mRNA levels. Conclusions: Diabetes-induced overexpression of TGF$\beta 1$ mRNA was suppressed by VE and INS after 5-, 7- and 10 -day treatments. The results obtained with the antioxidant VE suggest that oxidative stress is involved in the development of diabetic nephropathy. Therefore, VE treatment may be effective in early stages of diabetic nephropathy to decrease or prevent pathological complications.

Copyright (C) 2005 S. Karger AG, Basel

\section{Introduction}

Throughout the industrialized world, diabetes mellitus (DM) is the most prevalent cause of end-stage renal disease, and both incidence and prevalence of diabetic end-stage renal disease increased during the past decade in the US, Japan and Western Europe [1, 2]. Diabetic ne-

\section{KARGER}

Fax +4161306 1234

E-Mail karger@karger.ch

www.karger.com
C 2005 S. Karger AG, Basel

$1011-7571 / 05 / 0146-0422 \$ 22.00 / 0$

Accessible online at:

www.karger.com/mpp
Dr. Constantin Cojocel

Faculty of Medicine, Department of Pharmacology and Toxicology

Kuwait University, PO Box 24923

Safat 13110 (Kuwait)

Tel. +965 498 6342, Fax +965 534 2583, E-Mail ccojocel@yahoo.com 
phropathy (DN) is likely to develop over time in response to non-insulin-dependent diabetes (type 2) as well as to insulin (INS)-dependent DM (type 1). DN is an important cause of increased morbidity and mortality among these patients. Clinical manifestation of nephropathy is similar for the two main types of diabetes [3] despite differences in genetic predisposition [4]. Early nephromegaly, glomerular hyperfiltration and micro-albuminuria are equally prevalent in type 1 and type 2 diabetes $[3,5]$.

Toxic effects of glucose are well documented [6] and it is now firmly established that hyperglycemia is the main metabolic perturbation causing irreversible kidney damage in diabetes. Spontaneous chemical, non-enzymatic reaction(s) (known as Maillard reaction(s) [7]) between carbohydrates, such as glucose, and long-lived proteins lead to the formation of advanced glycation end products (AGEs) [8]. Reducing sugars, such as glucose, react nonenzymatically and reversibly with free amino groups in proteins giving Schiff base adducts and forming small amounts of stable Amadori products. Oxidative and nonoxidative reactions are both implicated in AGE formation and diabetic and non-diabetic complications $[9,10]$. AGEs and reactive precursors have been implicated in the pathogenesis of diabetes, Alzheimer disease, renal failure, and in normal aging [11-13]. Formation of AGEs is irreversible even at an early stage of diabetic complications.

Biological proteins are modified by AGE in vivo under 'oxidative stress' (glycoxidation). Increasing evidence suggests that oxidative damage results from a complex breakdown in oxidative balance, including increased generation of reactive oxygen species. Oxidative stress has a physiological role in signal transduction and it is involved in a wide array of deleterious cellular consequences such as DN [14].

Activation of cytokines might be another factor involved in the glomerular matrix accumulation in DN. It has been shown that hyperglycemia increases the expression of the cytokine-transforming growth factor (TGF$\beta 1)$ in glomeruli and matrix proteins $[15,16]$. Thus, TGF$\beta 1$ may contribute to both cellular hypertrophy and enhanced collagen synthesis in DN [17].

During diabetes, protein modification by Maillard reaction is associated with crosslinking [18], decreased protein solubility, increased protein resistance and amyloid formation. Inhibition of Maillard reactions using inhibitors of crosslinking, effective antioxidants and radical scavengers could contribute to the elucidation of molecular and biochemical mechanisms of $\mathrm{DN}$, and represents a promising therapeutic strategy with a potential to slow the progression of disease.

The aim of this study was to investigate the role played by oxidative stress in DN using an antioxidant and radical scavenger, vitamin E (VE), to modulate TGF- $\beta 1$ in early stages of DN. VE ( $\alpha$-tocopherol) is a fat-soluble antioxidant that is well suited to inhibit lipid peroxidation in the kidney cortex [18].

\section{Materials and Methods}

\section{Chemicals}

Chemicals were purchased from Sigma-Aldrich Chemie (Taufkirchen, Germany), unless otherwise specified.

\section{Animals and Treatment Groups}

Male Sprague-Dawley rats, weighing 200-220 g received standard laboratory diet and water ad libitum. Rats were housed in an environmentally controlled animal facility operating on a 12-hour dark/light cycle and 55\% humidity, and were maintained and cared for as described in the guide for the care and use of laboratory animals (Kuwait University).

To induce diabetes, rats were given a single i.p. injection of streptozotocin (STZ) $65 \mathrm{mg} / \mathrm{kg}$ dissolved in the $0.01 \mathrm{M}$ citrate buffer $\mathrm{pH} 4.5$ [19]. Control rats (termed 'vehicle') were given (i.p.) $0.01 M$ citrate buffer, $\mathrm{pH} 4.5$. On the 6th day following STZ injection, blood glucose levels were above $500 \mathrm{mg} / \mathrm{dl}(\sim 28 \mathrm{mM})$. On the 7 th day, diabetic rats were started on a course of treatment for 3 , 5,7 and 10 days with INS (7 IU/kg/day) [20], VE (100 mg/kg, i.p.), or a combination thereof. At least 5 rats were included in each treatment group. During the treatment period, each biochemical parameter was measured at 3, 5, 7 and 10 days. At the end of each treatment period, biochemical parameters were determined and the rats sacrificed. Biochemical parameters for the two control groups (vehicle and diabetic rats) were measured at 10 days, and the animals were sacrificed immediately thereafter.

\section{Determination of Total Protein, Lysozyme and TGF- $\beta 1$ in}

Plasma and Urine

At the end of the 10-day treatment period, animals (5/group) were placed in metabolic cages which permitted an effective separation of faeces and urine into tubes outside the cage. Urine collection was carried out over $24 \mathrm{~h}$; for this period the tubes used for urine collection were immersed in an ice-cold water bath to avoid losses in enzyme activity. Food and water were provided ad libitum over the collection period.

Total urine volume was determined gravimetrically, and the urine collected from each rat was centrifuged at 5,000 rpm and $4^{\circ} \mathrm{C}$ for 15 min using a Sorval ${ }^{\circledR}$ RT7 centrifuge (DuPont Medical Products, USA). Portions of urine from each animal were stored at $-20^{\circ} \mathrm{C}$ prior to protein, lysozyme and TGF- $\beta 1$ determinations. Total protein concentration in the urine was determined using the method of Schacterle and Pollack [21], and lysozyme activity was measured as described previously [22]. Total protein excretion was expressed as $\mathrm{mg} / 24 \mathrm{~h}$ and total lysozyme excretion as $\mu \mathrm{g} / 24 \mathrm{~h}$. Determination of TGF- $\beta 1$ in the plasma, the urine and the renal cortex was carried out using commercial ELISA kits (TGF $\beta 1$ 
Table 1. Effect of VE on non-fasting blood glucose and fructosamine concentrations in diabetic rats

\begin{tabular}{|c|c|c|c|c|c|c|c|c|c|c|c|c|c|c|}
\hline & \multicolumn{2}{|l|}{ Controls } & \multicolumn{12}{|c|}{ Treated diabetic rats } \\
\hline & vehicle & $\begin{array}{l}\text { diabetic } \\
\text { rats }\end{array}$ & INS & VE & INS + VE & INS & VE & $\mathrm{INS}+\mathrm{VE}$ & INS & VE & $\mathrm{INS}+\mathrm{VE}$ & INS & VE & $\mathrm{INS}+\mathrm{VE}$ \\
\hline $\begin{array}{l}\text { Glucose, } \\
\mathrm{mmol} / 1\end{array}$ & $\begin{array}{r}7.91 \\
\pm 0.08\end{array}$ & $\begin{array}{l}29.9 \\
\pm 3.37\end{array}$ & $\begin{array}{r}12.80 \\
\pm 0.43\end{array}$ & $\begin{array}{r}17.69 \\
\pm 2.67\end{array}$ & $\begin{array}{r}13.46 \\
\pm 3.05\end{array}$ & $\begin{array}{r}10.24 \\
\pm 1.65\end{array}$ & $\begin{array}{r}14.86 \\
\pm 1.01\end{array}$ & $\begin{array}{r}12.61 \\
\pm 2.77\end{array}$ & $\begin{array}{r}9.93 \\
\pm 1.50\end{array}$ & $\begin{array}{r}15.62 \\
\pm 0.98\end{array}$ & $\begin{array}{r}11.20 \\
\pm 2.80\end{array}$ & $\begin{array}{r}10.23 \\
\pm 0.33\end{array}$ & $\begin{array}{r}15.72 \\
\pm 3.24\end{array}$ & $\begin{array}{r}10.53 \\
\pm 0.23\end{array}$ \\
\hline $\begin{array}{l}\text { Fructosamine, } \\
\mathrm{mmol} / 1\end{array}$ & $\begin{aligned} & 0.147 \\
\pm & 0.01\end{aligned}$ & $\begin{array}{r}0.56 \\
\pm 0.03\end{array}$ & $\begin{array}{r}0.43 \\
\pm 0.03\end{array}$ & $\begin{array}{r}0.47 \\
\pm 0.04\end{array}$ & $\begin{array}{r}0.43 \\
\pm 0.01\end{array}$ & $\begin{array}{r}0.41 \\
\pm 0.08\end{array}$ & $\begin{array}{r}0.44 \\
\pm 0.03\end{array}$ & $\begin{array}{r}0.42 \\
\pm 0.04\end{array}$ & $\begin{array}{r}0.36 \\
\pm 0.02\end{array}$ & $\begin{array}{r}0.38 \\
\pm 0.01\end{array}$ & $\begin{array}{r}0.38 \\
\pm 0.02\end{array}$ & $\begin{array}{r}0.33 \\
\pm 0.04\end{array}$ & $\begin{array}{r}0.36 \\
\pm 0.01\end{array}$ & $\begin{array}{r}0.35 \\
\pm 0.06\end{array}$ \\
\hline
\end{tabular}

Data are mean \pm SD. Data from treated diabetic rats were statistically significant $(\mathrm{p}<0.05)$ when compared with data from non-treated diabetic rats.

$\mathrm{E}_{\max }{ }^{\circledR}$ ImmunoAssay System, Promega Corporation, USA). Plasma samples were diluted 150-fold for ELISA determination of TGF- $\beta 1$.

\section{Determination of Glycemic Stress}

Plasma glucose and fructosamine concentrations were measured and used as markers of glycemic stress. Plasma glucose concentrations were measured using a modification of the ortho-toluidine method [23]. Fructosamine concentrations were determined from formazan absorption at $530 \mathrm{~nm}$, as described previously [24, 25].

\section{Determination of Reduced Glutathione and Malondialdehyde} in the Renal Cortex

Reduced glutathione (GSH) was determined using Ellman's reagent and measurement of absorbance at $412 \mathrm{~nm}$ [26]. Oxidative damage caused to cell membrane lipids [27] was assessed by determination of thiobarbituric acid-reactive substances, mainly malondialdehyde (MDA), by means of absorbance at $535 \mathrm{~nm}$, as described previously $[27,28]$. Absorption spectra were recorded with a Beckman DU 70 spectrophotometer.

\section{Expression of TGF- $\beta 1 \mathrm{mRNA}$}

Expression of TGF- $\beta 1$ in the renal cortex was investigated using reverse transcription and polymerase chain reaction (RT-PCR). Total RNA was extracted from kidney cortex, and TGF- $\beta 1$ mRNA was measured semiquantitatively by RT-PCR using rat glutaraldehyde-3-phosphate dehydrogenase (GAPDH) mRNA as an internal control. PCR products were quantified using the Gel Documentation System (Gene Genius, Bio Imaging System, Syngene, Synoptics Ltd, UK).

Samples of $100 \mathrm{mg}$ of kidney cortex tissue were removed from treated and untreated rats and homogenized immediately in TRIzol reagent (Gibco-Invitrogen, UK). Total RNA was extracted from the homogenate according to the recommendations of the manufacturer. TGF- $\beta 1 \mathrm{mRNA}$ expression was determined by semiquantitative RT-PCR; $2 \mu \mathrm{g}$ of total RNA were reverse-transcribed and amplified using a one-step RT-PCR kit (Qiagen Inc., Calif., USA) according to the manufacturer's instructions. Primers used were: rat TGF- $\beta 1$ (sense); 5'-CTTCAGCTCCACAGAGAAGAACTGC-3' (bases 1,267-1,291), TGF- $\beta 1$ (antisense); 5'-CACGATCATGTTGGACAACTGCTCC-3' (bases 1,540-1,564); rat GAPDH (sense); 5'-ACCACAGTCCATGCCATCAC-3', GAPDH (antisense); 5'-TCCACCACCCTGTTGCTGTA-3' (bases 734763 ) giving predicted sizes of the amplified products of $298 \mathrm{bp}$ for TGF- $\beta 1$ and 452 bp for GAPDH. Total RNA was reverse-transcribed at $50^{\circ} \mathrm{C}$ for $20 \mathrm{~min}$, followed by amplification for 29 cycles of: denaturing for $30 \mathrm{~s}$ at $94^{\circ} \mathrm{C}$, annealing for $30 \mathrm{~s}$ at $58^{\circ} \mathrm{C}$ and extension for $30 \mathrm{~s}$ at $72^{\circ} \mathrm{C}$ using a DNA thermal cycler (Perkin-Elmer Cetus, Instruments, USA). Those conditions yielded exponential amplifications as described previously [29]. Samples (5 $\mu$ l) of RTPCR product were analyzed by electrophoresis on a $1 \%$ agarose gel and visualized by ethidium bromide staining. Levels of TGF- $\beta$ mRNA expression were determined after normalization for GAPDH mRNA.

TGF- $\beta$ mRNA levels in the renal cortex were also examined by Northern blot analysis. Total RNA $(10 \mu \mathrm{g})$ samples were separated by electrophoresis on $1 \%$ formaldehyde-agarose and transferred onto positively charged nylon membranes. RNA species were detected with biotin-labeled TGF- $\beta$ and GAPDH probes using BrightStar BioDetect Kit (Ambion, USA) following the manufacturer's protocols, and were quantified using a gel documentation system (Gene Genius, Syngene, UK).

\section{Statistical Evaluation of Results}

Mean values, standard deviations (SD) and one-way ANOVA were carried out using Sigma software (Jandel Scientific Software, San Rafael, Calif., USA). ANOVA was followed by the StudentNewman-Keuls test. Results were considered statistically significant if $\mathrm{p}<0.05$.

\section{Results}

\section{Glycemic Stress}

A significant increase in plasma glucose and fructosamine concentrations was observed after induction of diabetes in rats (table 1). Glycemic stress was decreased by treatment of diabetic rats with INS, VE or by the combination of INS and VE. VE treatment for 10 days reduced glucose and fructosamine levels to 47.42 and $32.51 \%$, respectively, compared to the corresponding levels in diabetic rats. 
Table 2. Effect of VE on renal glucose, total protein und lysozyme excretion in diabetic rats

\begin{tabular}{|c|c|c|c|c|c|c|c|c|c|c|c|c|c|c|}
\hline & \multicolumn{2}{|l|}{ Controls } & \multicolumn{12}{|c|}{ Treated diabetic rats } \\
\hline & \multirow[t]{2}{*}{ vehicle } & \multirow{2}{*}{$\begin{array}{l}\text { diabetic } \\
\text { rats }\end{array}$} & \multicolumn{3}{|l|}{3 days } & \multicolumn{3}{|l|}{5 days } & \multicolumn{3}{|l|}{7 days } & \multicolumn{3}{|l|}{10 days } \\
\hline & & & INS & VE & $\mathrm{INS}+\mathrm{VE}$ & INS & VE & $\mathrm{INS}+\mathrm{VE}$ & INS & VE & INS + VE & INS & VE & $\mathrm{INS}+\mathrm{VE}$ \\
\hline $\begin{array}{l}\text { Excretion of } \\
\text { glucose, } \\
\mathrm{mmol} / 24 \mathrm{~h}\end{array}$ & $\begin{aligned} & 0.8581 \\
\pm & 0.12\end{aligned}$ & $\begin{array}{r}1,145.47 \\
\pm 88.36\end{array}$ & $\begin{array}{r}910.59 \\
\pm 16.59\end{array}$ & $\begin{array}{r}953.09 \\
\pm 11.75\end{array}$ & $\begin{array}{l}916 \\
\pm 20.16\end{array}$ & $\begin{array}{r}805.26 \\
\pm 12.39\end{array}$ & $\begin{array}{r}913.77 \\
\pm 11.89\end{array}$ & $\begin{array}{r}842.34 \\
\pm 31.65\end{array}$ & $\begin{array}{r}813.49 \\
\pm 5.66\end{array}$ & $\begin{array}{r}867.84 \\
\pm 7.86\end{array}$ & $\begin{array}{r}775.89 \\
\pm 28.81\end{array}$ & $\begin{array}{r}555.42 \\
\pm 28.78\end{array}$ & $\begin{array}{r}611.42 \\
\pm 17.36\end{array}$ & $\begin{array}{r}558.36 \\
\pm 14.11\end{array}$ \\
\hline $\begin{array}{l}\text { Total protein } \\
\text { excretion, } \\
\mathrm{mg} / 24 \mathrm{~h}\end{array}$ & $\begin{array}{r}73.44 \\
\pm 4.84\end{array}$ & $\begin{array}{l}148.8 \\
\pm 7.23\end{array}$ & $\begin{array}{r}120.96 \\
\pm 6.24\end{array}$ & $\begin{array}{r}124.80 \\
\pm 6.72\end{array}$ & $\begin{array}{r}124.32 \\
\pm 10.08\end{array}$ & $\begin{array}{r}119.28 \\
\pm 0.72\end{array}$ & $\begin{array}{r}116.64 \\
\pm 1.78\end{array}$ & $\begin{array}{r}112.56 \\
\pm 1.70\end{array}$ & $\begin{array}{r}113.76 \\
\pm 3.36\end{array}$ & $\begin{array}{r}120.96 \\
\pm 6.72\end{array}$ & $\begin{array}{r}110.40 \\
\pm 7.68\end{array}$ & $\begin{array}{r}102.72 \\
\pm 1.38\end{array}$ & $\begin{array}{r}103.68 \\
\pm 3.12\end{array}$ & $\begin{array}{r}100.32 \\
\pm 7.68\end{array}$ \\
\hline $\begin{array}{l}\text { Lysozyme } \\
\text { excretion, } \\
\mu \mathrm{g} / 24 \mathrm{~h}\end{array}$ & $\begin{array}{r}37.11 \\
\pm 4.56\end{array}$ & $\begin{array}{r}194.88 \\
\pm 12.72\end{array}$ & $\begin{array}{r}179.76 \\
\pm 2.88\end{array}$ & $\begin{array}{l}179.04 \\
\pm 4.8\end{array}$ & $\begin{array}{r}173.76 \\
\pm 6.00\end{array}$ & $\begin{array}{r}132.24 \\
\pm 8.40\end{array}$ & $\begin{array}{r}147.12 \\
\pm 2.64\end{array}$ & $\begin{array}{r}142.80 \\
\pm 6.24\end{array}$ & $\begin{array}{r}115.20 \\
\pm 9.36\end{array}$ & $\begin{array}{r}125.76 \\
\pm 14.16\end{array}$ & $\begin{array}{c}129.6 \\
\pm 9.12\end{array}$ & $\begin{array}{r}106.32 \\
\pm 12.24\end{array}$ & $\begin{array}{r}88.80 \\
\pm 3.12\end{array}$ & $\begin{array}{r}94.08 \\
\pm 7.92\end{array}$ \\
\hline
\end{tabular}

Data are mean \pm SD. Data from treated diabetic rats were statistically significant $(\mathrm{p}<0.05)$ when compared with data from non-treated diabetic rats.

Table 3. Effect of VE on renal glutathione content and lipid peroxidation in diabetic rats

\begin{tabular}{|c|c|c|c|c|c|c|c|c|c|c|c|c|c|c|}
\hline & \multicolumn{2}{|c|}{ Controls } & \multicolumn{12}{|c|}{ Treated diabetic rats } \\
\hline & \multirow[t]{2}{*}{ vehicle } & \multirow{2}{*}{$\begin{array}{l}\text { diabetic } \\
\text { rats }\end{array}$} & \multicolumn{3}{|l|}{3 days } & \multicolumn{3}{|l|}{5 days } & \multicolumn{3}{|l|}{7 days } & \multicolumn{3}{|c|}{10 days } \\
\hline & & & INS & VE & $\mathrm{INS}+\mathrm{VE}$ & INS & VE & $\mathrm{INS}+\mathrm{VE}$ & INS & VE & $\mathrm{INS}+\mathrm{VE}$ & INS & VE & INS + VE \\
\hline $\begin{array}{l}\text { Glutathione } \\
\text { (nmol/g tissue) }\end{array}$ & $\begin{array}{r}5.42 \\
\pm 0.18\end{array}$ & $\begin{array}{r}3.28 \\
\pm 0.16\end{array}$ & $\begin{array}{r}3.80 \\
\pm 0.24\end{array}$ & $\begin{array}{r}3.74 \\
\pm 0.27\end{array}$ & $\begin{array}{r}3.70 \\
\pm 0.06\end{array}$ & $\begin{array}{r}4.12 \\
\pm 0.15\end{array}$ & $\begin{array}{r}4.14 \\
\pm 0.05\end{array}$ & $\begin{array}{r}4.06 \\
\pm 0.08\end{array}$ & $\begin{array}{r}4.59 \\
\pm 0.31\end{array}$ & $\begin{array}{r}4.66 \\
\pm 0.36\end{array}$ & $\begin{array}{r}4.60 \\
\pm 0.08\end{array}$ & $\begin{array}{r}4.88 \\
\pm 0.23\end{array}$ & $\begin{array}{r}4.90 \\
\pm 0.48\end{array}$ & $\begin{array}{r}4.79 \\
\pm 0.07\end{array}$ \\
\hline $\begin{array}{l}\text { Malondialdehyde } \\
\text { (nmol/g tissue) }\end{array}$ & $\begin{array}{r}30.14 \\
\pm 2.21\end{array}$ & $\begin{array}{r}38.79 \\
\pm 3.36\end{array}$ & $\begin{array}{r}35.46 \\
\pm 2.32\end{array}$ & $\begin{array}{r}36.96 \\
\pm 1.06\end{array}$ & $\begin{array}{r}35.60 \\
\pm 2.25\end{array}$ & $\begin{array}{r}34.46 \\
\pm 3.31\end{array}$ & $\begin{array}{r}32.68 \\
\pm 2.42\end{array}$ & $\begin{array}{r}34.38 \\
\pm 3.24\end{array}$ & $\begin{array}{r}29.86 \\
\pm 4.33\end{array}$ & $\begin{array}{r}28.41 \\
\pm 3.91\end{array}$ & $\begin{array}{r}29.10 \\
\pm 2.70\end{array}$ & $\begin{array}{r}27.69 \\
\pm 1.42\end{array}$ & $\begin{array}{r}26.32 \\
\pm 2.68\end{array}$ & $\begin{array}{r}26.09 \\
\pm 2.29\end{array}$ \\
\hline
\end{tabular}

Data are mean $\pm \mathrm{SD}$. Data from treated diabetic rats were statistically significant $(\mathrm{p}<0.05)$ when compared with data from non-treated diabetic rats.

\section{Renal Excretion of Glucose, Total Protein and \\ Lysozyme}

Since diabetes causes glomerular and tubular changes, marker proteins, such as lysozyme, may be used to detect early renal damage. Excretion of glucose, total protein and lysozyme increased significantly in diabetic rats when compared with control (vehicle) values (table 2). Treatment of diabetic rats with INS, VE or the combination of INS and VE depressed these diabetes-induced complications. VE treatment of diabetic rats for 10 days reduced glucose, total protein and lysozyme excretion to 46.62 , 30.32 and $54.43 \%$, respectively, when compared with the corresponding levels in non-treated diabetic rats (table 2).

\section{Oxidative Stress}

A decrease of GSH in the cortex of diabetic rats, when compared with vehicle-treated animals, was found (table 3). Treatment of diabetic rats with INS, VE and the combination of INS and VE over 3-10 days caused a par- tial recovery of GSH content. VE treatment for 10 days of diabetic rats increased GSH content by $33.06 \%$, when compared with the corresponding levels in non-treated diabetic animals (table 3 ).

MDA content increased in the renal cortex of diabetic rats when compared with vehicle-treated animals (table 3). Treatment of diabetic rats with INS, VE and the combination of INS and VE over 3-10 days showed a decrease of MDA content towards the values observed in vehicle-treated animals. VE treatment for 10 days of diabetic rats decreased the formation of MDA to $32.14 \%$, when compared with the corresponding levels in nontreated diabetic rats (table 3 ).

\section{Plasma TGF- $\beta 1$ and Excretion of TGF- $\beta 1$}

There was a significant increase in TGF- $\beta 1$ excretion in diabetic rats compared with control animals (fig. 1). Plasma TFG- $\beta 1$ concentrations increased significantly in diabetic rats (fig. 1) but returned to control values in treated diabetic groups. After 10 days of VE treatment, plasma 


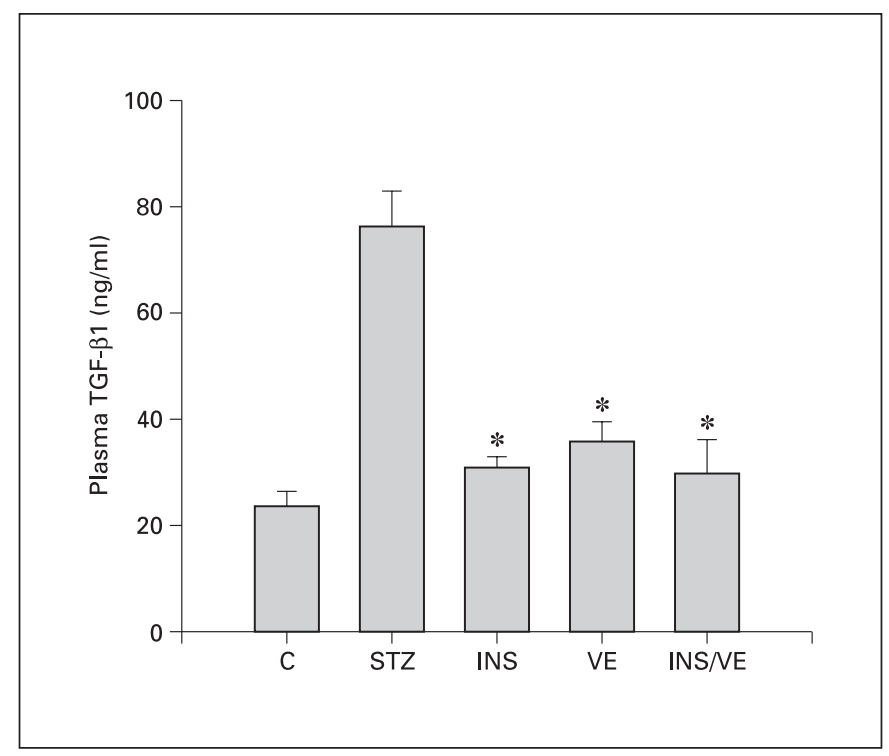

Fig. 1. Plasma concentration of TGF- $\beta 1$ in the rat groups. $C=$ Control (vehicle); STZ = diabetic rats; INS = diabetic rats treated with INS; VE = diabetic rats treated with VE; INS/VE = diabetic rats treated with INS and VE. Treatment of diabetic rats was carried out for 10 days. Plasma samples were diluted 150-fold before determination. Mean values $\pm \mathrm{SD}$ of at least 5 rats are depicted. * Statistically significant $(\mathrm{p}<0.05)$ difference between treated diabetic rats and non-treated diabetic rats.

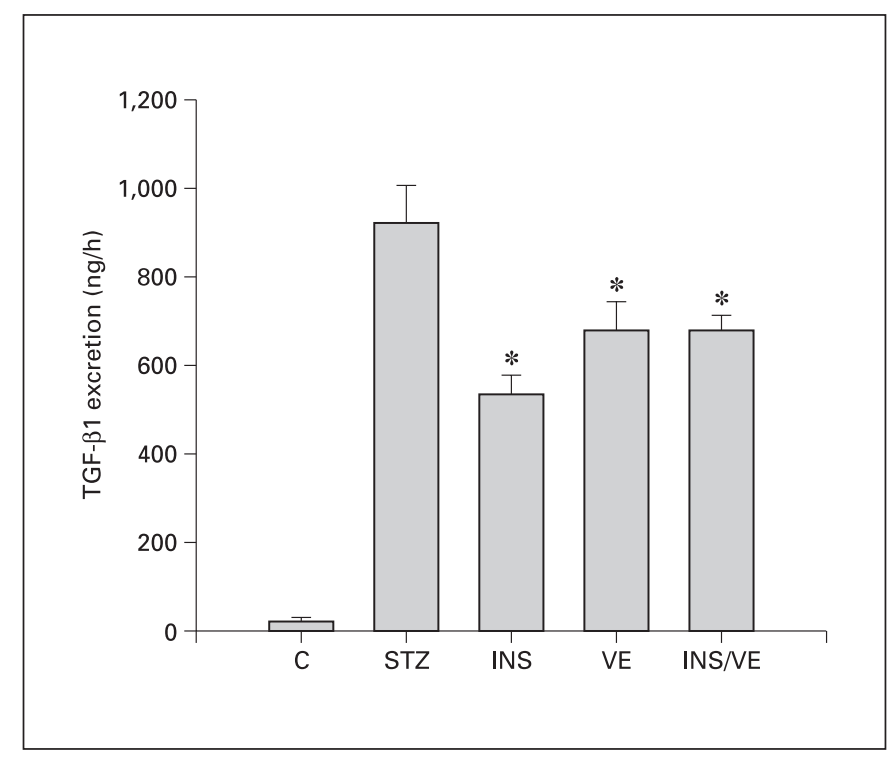

Fig. 2. Renal excretion of TGF- $\beta 1$ in the rat groups. Treatment of diabetic rats was carried out for 10 days. Mean values \pm SD of at least 5 rats are depicted. * Statistically significant $(\mathrm{p}<0.05)$ difference between treated diabetic rats and non-treated diabetic rats.

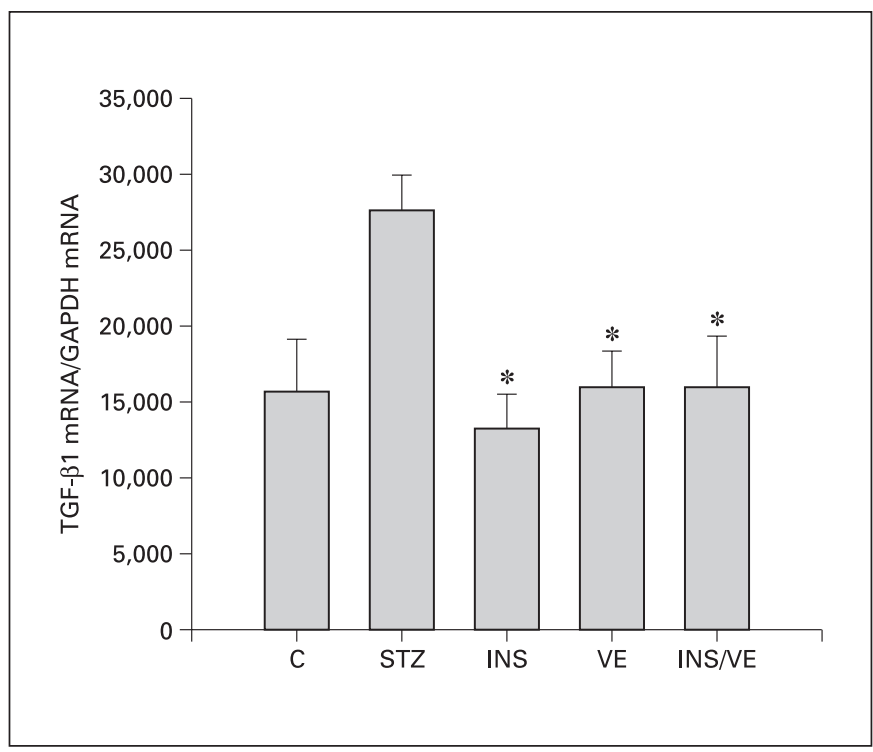

Fig. 3. Ratio of TGF- $\beta 1 \mathrm{mRNA} / \mathrm{GAPDH} \mathrm{mRNA}$ in the renal cortex tissue of rats. Treatment of diabetic rats was carried out for 10 days. GAPDH mRNA was used as an internal control. Mean values \pm SD of at least 5 rats are depicted. * Statistically significant $(\mathrm{p}<$ 0.05 ) difference between treated diabetic rats and non-treated diabetic rats.

concentration of TGF- $\beta 1$ decreased by $53.75 \%$, when compared with non-treated diabetic rats. After 10-day treatment of diabetic rats with INS, VE, or the combination of INS and VE, there was an effective inhibition of TGF- $\beta 1$ excretion in treated diabetic rats when compared with values from non-treated diabetic rats (fig. 2); after VE treatment, TGF- $\beta 1$ excretion decreased by $25.64 \%$.

\section{Expression of TGF- $\beta 1 \mathrm{mRNA}$}

There was a significant overexpression of the TGF- $\beta 1$ mRNA in diabetic rats, when compared with controls, as determined by RT-PCR (fig. 3). Treatment of diabetic rats with INS, VE and the combination of INS and VE for 10 days caused a decrease in the overexpression towards control values (fig. 3). After 10 days VE treatment, the overexpression of TGF- $\beta 1$ mRNA decreased by $41.46 \%$, when compared with non-treated diabetic rats. Northern blot analysis gave a similar pattern of expression of TGF- $\beta$ mRNA in the control and treated rats (fig. 4). Overexpression of the TGF- $\beta 1 \mathrm{mRNA}$ decreased in the VE group by $32.30 \%$, when compared with values from diabetic non-treated animals. 


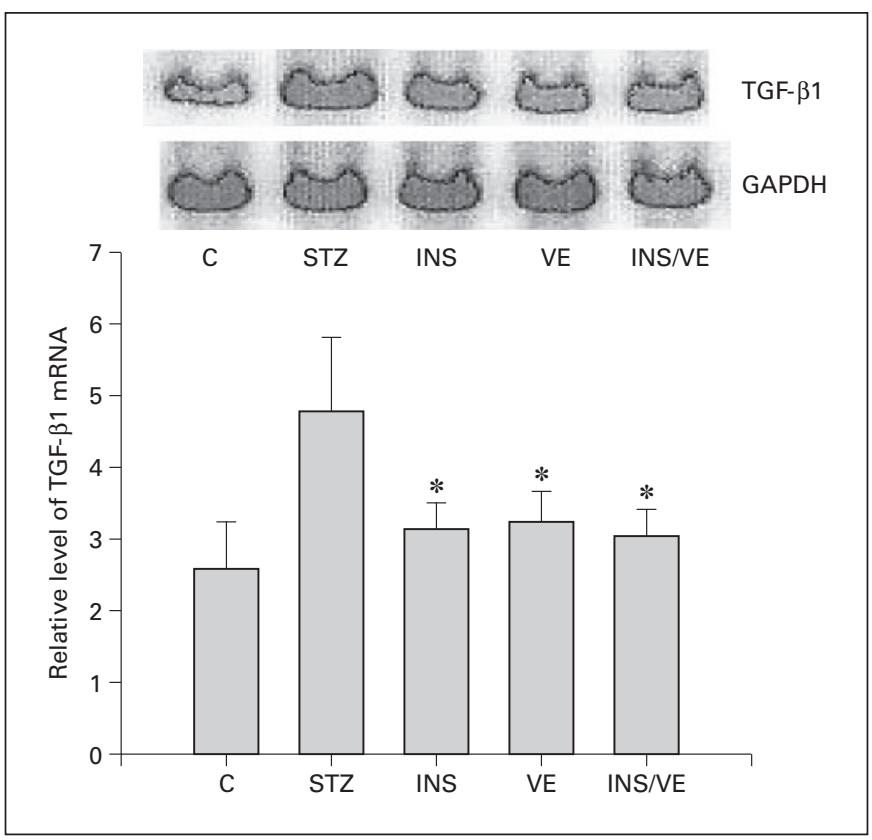

Fig. 4. Expression of TGF- $\beta$ mRNA in the renal cortex of rats. Total RNA was extracted and Northern blot analysis performed as described in 'Materials and Methods'. In the upper panel Northern blots representative of those obtained from at least four independent experiments. In the lower panel the results of Northern blot analysis normalized to GAPDH mRNA. Treatment of diabetic rats was carried out for 10 days. Mean values \pm SD of at least 5 rats are depicted. $*$ Statistically significant $(p<0.05)$ difference between treated diabetic rats and non-treated diabetic rats.

\section{Discussion}

In STZ-treated rats, DM arises from irreversible destruction of pancreatic $\beta$-cells, causing reduction of INS secretion [30]. Therefore, STZ-induced DM has been used in numerous studies as an animal model of human type $1 \mathrm{DM}$.

It is important to consider oxidative stress as a potential source of patient morbidity and mortality in diabetes. The present study showed that VE had an antihyperglycemic effect in STZ-induced diabetic rats. VE also had a protective effect against oxidative stress in the kidney induced by hyperglycemia. The plasma concentration of fructosamine is a parameter that reflects the overall metabolic control of diabetes over the time following STZ administration [31]. In the present study, plasma concentrations of fructosamine were decreased in VE and in VE and INS treatment groups in diabetic rats. This supports the antihyperglycemic effect of $\mathrm{VE}$ and is in accordance with results from patient studies showing that VE im- proves INS action [32]. The antihyperglycemic effect of VE is also supported by a significant decrease of glucose excretion in VE-treated groups compared with non-treated diabetic rats in this study.

An increased excretion of total protein is an indicator of glomerular damage [33], while an increased excretion of low molecular weight proteins, such as lysozyme, is an indicator of tubular structural and functional injuries [34]. The present findings regarding the increase of total protein excretion in diabetic rats are in agreement with previous studies [35]. The present study showed that both total protein excretion and lysozyme excretion were significantly increased in diabetic rats (when compared with non-diabetic controls), and that in VE and in INS plus VE treatment groups a distinct depression of these two indicators occurred. Similarly, a study of diabetic patients showed that treatment with VE significantly decreased microalbuminuria [36], indicating a nephroprotective effect of VE in diabetes.

Increased plasma concentrations of TGF- $\beta 1$ and increased excretion of TGF- $\beta 1$ in the urine suggests that TGF- $\beta 1$ may have a role in the pathogenesis of tubulointerstitial disease that characterizes proteinuric renal disease in diabetic rats. The present study indicates that levels of urinary TGF- $\beta 1$ were related to total protein and lysozyme excretion. TGF- $\beta 1$ excretion was decreased in diabetic rats treated with VE and VE plus INS when compared with non-treated diabetic rats. This suggests that TGF- $\beta 1$ could be implicated in the tubulointerstitial fibrosis that accompanies proteinuric renal disease in $\mathrm{DN}$. The fibrotic build-up in the tubulo-interstitium is probably a result of excessive production of matrix by tubular epithelial and interstitial cells stimulated by increased TGF- $\beta 1$ activity.

Many pathogenic mechanisms contribute to the development of DN; oxidative damage is one of them [37]. GSH which is the primary endogenous antioxidant, and MDA, a marker of oxidative stress, were measured in the renal cortex of diabetic rats at different time points after STZ injection.

This showed a distinct decrease of the tripeptide GSH in the renal cortex of diabetic rats when compared with control rats. Treatment of diabetic rats with VE or with VE plus INS caused a recovery of GSH content towards control values. Thus it appears that GSH is implicated in cellular protection against reactive oxygen species. MDA, an end product of lipid peroxidation, was increased in the renal cortex of diabetic rats, suggesting that peroxidative injury may be involved in the development of DN. In this study, treatments of diabetic rats with VE, or with the 
combination of VE and INS reduced the MDA content in the renal cortex, suggesting that VE can protect renal cortex tissue against lipid peroxidation through its antioxidant effect [38]. The early protective effect of VE may be due to its antihyperglycemic effect and/or its free radical-scavenging effect.

Members of the TGF- $\beta$ superfamily are synthesized as prepropeptides precursors and then processed and secreted as homodimers and heterodimers. The TGF- $\beta 1$ family of peptide growth factors includes five members, termed TGF- $\beta 1$ through TGF- $\beta 5$, all of which form homodimers of about $25 \mathrm{kDa}$. TGF- $\beta$ s have been shown to exert a number of different effects in a variety of cells [39]. TGF- $\beta 1$ has many biological functions, including regulating cell activation, proliferation, differentiation and viability and promoting tissue regeneration and repair. The present study showed that TGF- $\beta 1$ mRNA is increased in the renal cortex of type 1 diabetic rats and is in agreement with the results of previous studies [40].

\section{Conclusion}

Diabetes-induced overexpression of TGF- $\beta 1 \mathrm{mRNA}$ was suppressed significantly by VE and INS after 5-, 7and 10-day treatments in this study. Therefore, VE treatment may be effective in early stages of DM to decrease or prevent $\mathrm{DN}$ complications. A better understanding of the role of protein glycation reactions, and of oxidative stress and intracellular signaling in the development of diabetes will help to establish therapies to delay the onset and progression of diseases such as DN.

\section{Acknowledgements}

This work was supported by grants No. MR 01/00, MI 03/00, MI05/02 and KU-MB 01/01 from Kuwait University Research Administration, Kuwait.

\section{References}

1 Schena FP: Epidemiology of end-stage renal disease: internal comparisons of renal replacement therapy. Kidney Int 2000;57:S-39-S-45.

$\checkmark 2$ Friedman EA: Advanced glycation end-products in diabetic nephropathy. Nephrol Dial Transplant 1999;14(suppl 3):1-9.

-3 Biesenbach G, Janko O, Zazgomik J: Similar rate of progression in the predialysis phase in type I and type II diabetes mellitus. Nephrol Dial Transpl 1994;9:1097-1102.

-4 Sheehy MJ: HLA and insulin-dependent diabetes. A protective perspective. Diabetes 1992; 41:123-129.

5 Wirta O, Pastemack A, Laippala P, Turjanama V: Glomerular filtration rate kidney size after six years of disease duration in non-insulin-dependent diabetic subjects. Clin Nephrol 1996; 45:10-17.

-6 Porte D Jr, Schwartz MW: Diabetes complications: why is glucose potentially toxic? Science 1996;272:699-700.

7 Maillard LC: Action des acides aminés sur les sucres: formation des mélanoïdines par voie méthodique. C R Acad Sci 1912;154:66.

-8 Brownlee M, Cerami A, Vlassara H: Advanced glycosylation end products in tissue and the biochemical basis of diabetic complications. $\mathrm{N}$ Engl Med 1998;318:1315-1321.

-9 Baynes JW: Perspectives in diabetes. Role of oxidative stress in development of complications in diabetes. Diabetes 1991;40:405-412.
10 Meng J, Sakata N, Imanaga Y, Tachikawa Y, Chihara J, Takebayashi S: Evidence for a link between glycoxidation and lipoperoxidation in patients with chronic renal failure. Clin Nephrol 1991;51:280-289.

11 Monnier VM, Nagaraj RH, Portero-Otin M, Glomb M, Elgawish AH, Sell DR, Friedlander MA: Structure of advanced Maillard reaction products and their pathological role. Nephrol Dia Transplant 1966;11(suppl 5):20-26.

12 Munch G, Mayer S, Michaelis J, Hipkiss AR, Riederer P, Muller R, Neumann A, Schinzel R, Cunningham AM: Influence of advanced glycation end-products and AGE-inhibitors on nucleation-dependent polymerizaton of betaamyloid peptide. Biochim Biophys Acta 1997 1360:17-29.

13 Smith MA, Sayre LM, Vitek MP, Monnier VM, Perry G: Early AGEing and Alzheimer's. Nature 1995;374:316.

14 Cooper ME: Pathogenesis, prevention, and treatment of diabetic nephropathy. Lancet 1998;352:213-219.

15 Sharma K, Ziyadeh FN: Hyperglycemia and diabetic kidney disease: the case for transforming growth factor-beta as a key mediator. Diabetes 1995:44:1139-1146.

16 Wolf G, Ziyadeh FN: Molecular mechanisms of diabetic renal hypertrophy. Kidney Int 1999;56:393-405.

17 Border WA, Noble NA: Evidence that TGFbeta should be a therapeutic target in diabetic nephropathy. Kidney Int 1998;54:13901391.
18 Cojocel C, Laeschke KH, Inselmann G, Baumann K: Inhibition of cephaloridine-induced lipid peroxidation. Toxicology 1985;35:295305 .

19 Agardh E, Hultberg B, Agardh C: Effects of inhibition of glycation and oxidative stress on the development of cataract and renal vessel abnormalities in diabetic rats. Curr Eye Res 2000;21:543-549.

20 Al-Awadi FM, Al-Adnan MS: Structural changes in glomeruli and proteinuria in streptozotocin diabetic rats. Histol Histopathol 1989;4:129-135.

21 Schacterle GR, Pollack RL: A simplified method for quantitative assay of small amounts of protein in biological material. Anal Biochem 1973;51:654-655.

22 Cojocel C, Baumann K: Renal handling of endogenous lysozyme in the rat. Ren Physiol 1983;6:258-265

23 Viner BM, Kisel VL, Krendal PP, Rubtsova ER: A modification of ortho-toluidine method for determining glucose in the blood. Eksp Klin Farmakol 1973;56:62-64.

24 Johnson RN, Metcalf PA, Backer JR: Fructosamine: a new approach to the estimation of serum glycosylprotein. An index of diabetic control. Clin Chim Acta 1982;127:87-95.

25 Backer JR, Metcalf PA, Johnson RN: Use of protein-based standards in automated colorimetric determinations of fructosamine in serum. Clin Chem 1985;31:1550-1554. 
-26 Ellman GL: Tissue sulfhydryl groups. Arch Biochem Biophys 1959;82:70-77.

27 Buege JA, Aust SD: Microsomal lipid peroxidation. Methods Enzymol 1978;52:302-312.

-28 Dogra S, Filser JG, Cojocel C, Greim H, Regel U, Oesch F, Robertson LW: Long-term effects of commercial and congeneric polychlorinated biphenyls on ethane production and malondialdehyde levels, indicators of in vivo lipid peroxidation. Arch Toxicol 1988;62:369-374.

-29 Tsunoda S, Yamabe H, Osawa H, Kaizuka M, Shirato K, Okumura K: Cultured rat glomerular epithelial cells show gene expression and production of transforming growth factor- $\beta$ : expression is enhanced by thrombin. Nephrol Dial Transplant 2001;16:1776-1782.

-30 Junod A, Lambert AE, Atauffacher W, Renold AE: Diabetogenic action of streptozotocin: relationship of dose to metabolic response. J Clin Invest 1969;48:2129-2139.
31 Montilla PL, Vargas JF, Tunez IF, Munoz de Agueda MC, Valdelvira ME, Cabrera ES: Oxidative stress in diabetic rats induced by streptozotocin: protective effects of melatonin. Pineal Res 1998;25:94-100.

32 Paolisso G, D'Amore A, Giugliano D, Ceriello A, Varricchio M, D’Onofrio F: Pharmacological doses of vitamin $\mathrm{E}$ improves insulin action. Am J Clin 1993;57:650-656.

33 Lehmann R, Schleicher ED: Molecular mechanisms of diabetic nephropathy. Clin Chim Acta 1993;297:135-144.

34 Baumann K, Cojocel C: Microperfusion and clearance studies on renal protein reabsorption. Contr Nephrol 1981;24:8-17.

35 Koya D, Haneda M, Kikkawa R, King GL: dalpha-tocopherol treatment prevents glomerular dysfunction in diabetic rats through inhibition of protein kinase C-dicylglycerol pathway. Biofactors 1998;7:69-76.

- 36 Hirnerova E, Krahulec B, Strbova L, Stecova A, Dekret J, Hajovska A: Effect of vitamin E therapy on progression of diabetic nephropathy. Vnitr Lek 2003;49:529-534.
37 Koya D, Hayashi K, Kitada M, Kashiwagi A, Haneda M: Effects of antioxidants in diabetesinduced oxidative stress in the glomeruli of diabetic rats. J Am Soc Nephrol 2003;14: S250-S253.

- 38 Kedziora-Kornatowska K, Szram S, Kornatowski T, Szaduijkis-Szadurski L, Kezdiora J, Bartosz G: Effects of vitamin E and vitamin C supplementation on oxidative state and renal glomerular basement membrane thickness in diabetic kidneys. Nephron Exp Nephrol 2003; 95:e134-e143.

39 de Caestecker M: The transforming growth factor-beta superfamily of receptors. Cytokine Growth Factor Rev 2004;15:1-11.

40 Yamamoto T, Nakamura T, Noble NA Ruoslahti E, Border WA: Expression of transforming growth factor beta is elevated in human and experimental diabetic nephropathy. Proc Natl Acad Sci USA 1993;90:1814-1818. 